\title{
O CORPO QUE LE \\ AFETO, MATERIALIDADE E LEITURA EM OS DETETIVES SELVAGENS, DE ROBERTO BOLAÑO
}

Natalie Araújo Lima é doutoranda em Literatura, Cultura e Contemporaneidade pela PUC-RIO e bolsista Capes. O presente artigo faz parte da dissertação de mestrado Em meio às vísceras: Ensaios sobre leitura em dois romances de Roberto Bolaño, desenvolvida com apoio da bolsa CNPQ e defendida em março de 2013 pelo Programa de Literatura Cultura e Contemporaneidade da PUC-Rio, sob a orientação da professora Rosana Kohl Bines.

E-mail: nataliearaujolima@gmail.com

\section{Resumo}

Este trabalho apresenta a relação-limite entre texto e leitor. Papel e pele se tocam, importando menos o conteúdo lido e mais o ato em si, assim como os movimentos ex-cêntricos que derivam disso.

\section{Resumen}

Este trabajo presenta la relación-límite entre texto y lector. Papel y piel se tocan, el acto en si mismo importa más que el contenido leído, así como los movimientos ex-céntricos que derivan de ahí.

\section{1) A escritura dos corpos}

Em setembro de 1977, na rue des Petites Écuries, em Paris, Simone Darrieux, uma francesa com quem Arturo Belano teve um caso enquanto ainda morava no México, conta de que forma conheceu Ulises Lima: um dia ele bateu à porta dela dizendo-se amigo de Belano, e isso bastou para que estabelecessem uma relação bastante formal em que ele a convidava para sair e Simone geralmente negava. Ulises, conta ela, alugara uma chambre de bonne na rue des Eaux. O local era infecto e disso ele tinha plena noção (nesse quarto chegou até mesmo a contrair sarna, fato do qual Simone nunca tomou conhecimento). No entanto, estava disposto a permanecer ali enquanto durasse sua temporada na cidade; não queria perder tempo procurando outro lugar para ficar. O cômodo que alugara era desprovido de banheiro, o que o obrigava a frequentar os públicos e a tomar banho na casa de Simone uma vez por semana. Segundo ela, Ulises tentava não deixar vestígios de sua passagem: antes de sair do chuveiro recolhia todos os fios de cabelo que haviam ficado presos no ralo.

Em pouco tempo - provavelmente devido não só aos cabelos compridos, mas igualmente à sua aparente ingenuidade e à sua polidez - ficou conhecido como o Cristo da rue des Eaux, afirma Sofía Pellegrini, em depoimento dado também em setembro de 1977. Embora nunca tenha ido visitá-lo, ela sabe, pelo que os outros lhe contavam, que a casa de Ulises era um "muquifo", "que ali se acumulavam os objetos mais inúteis de Paris: lixo, revistas, jornais, livros que ele roubava das livrarias e que logo adquiriam seu cheiro, logo apodreciam, floresciam, ganhavam cores alucinantes" (Bolaño, 2010, p. 241).

Um acumulador de livros que são alterados em sua materialidade; um corpo humano que toca corpos de papel e os faz apodrecer ou florescer, que os impregna com seu cheiro. Esse é o mesmo corpo que, diz Simone Darrieux, embora não dominasse o 
francês, "tinha sempre vários livros debaixo do braço", todos nesse idioma. (Idem, Ibidem, p. 233); um corpo que lia compulsivamente e que era capaz de estabelecer com os livros um contato que ultrapassava uma relação asséptica. Ou melhor, que podia contaminar algo higiênico, como o ato de tomar banho, com sua relação visceral com a leitura. Simone é uma testemunha dessa potência:

Era um tipo curioso. Escrevia na margem dos livros. Por sorte nunca lhe emprestei nenhum. Por quê? Porque não gosto que escrevam em meus livros. E ele fazia uma coisa mais chocante do que escrever nas margens. Provavelmente vocês não vão acreditar em mim, mas ele entrava no banho com um livro. Juro. Lia no chuveiro. Como sei? Muito fácil. Quase todos os livros dele estavam molhados. No início, eu pensava que era por causa da chuva, Ulises era um andarilho, raras vezes pegava metrô, percorria Paris de ponta a ponta andando e, quando chovia, se molhava todo porque nunca parava para esperar a chuva passar. De modo que seus livros, pelo menos os que ele lia mais, estavam sempre meio ondulados, como que apergaminhados, e eu achava que era por causa da chuva. Mas um dia percebi que entrava no banho com um livro seco e que, ao sair, o livro estava molhado. Esse dia minha curiosidade foi mais forte do que minha discrição. Eu me aproximei dele e lhe arranquei o livro das mãos. Não só a capa estava molhada, algumas folhas também, e as anotações na margem, com a tinta desbotada pela água, algumas talvez escritas debaixo d'água, então eu disse a ele meu Deus, não posso acreditar, você lê no chuveiro! Está doido? E ele disse que não conseguia evitar, que ainda por cima só lia poesia, não entendi o motivo pelo qual ele especificou que só lia poesia, não entendi naquele momento, agora sim entendo, queria dizer que só lia uma, duas ou três páginas, não um livro inteiro, e então desatei a rir, eu me joguei no sofá e me torci de rir, ele também começou a rir, rimos os dois, um tempão, não me lembro mais quanto (Idem, Ibidem, pp. 242 - 243).

O papel e a pele se tocam. Ulises experimenta esse contato não apenas escrevendo nos próprios livros quando estão secos - leva a relação ao limite, à água de um chuveiro que deveria apenas servir para limpá-lo, mas que borra a tinta de suas anotações e que, supomos, o faz querer tocar a superfície molhada do poema e também ser tocado por ela. Aqui o corpo do homem e o corpo do texto - embora Ulises leia o poema, embora um sujeito esteja diante de um objeto, é também tocado por ele - não são significantes nem significados, mas espaços abertos, superfícies de contato: Bolaño constrói uma cena em que o conteúdo lido por Ulises parece importar menos que a atividade de leitura em si. Não sabemos o que o personagem lê, apenas que lê. A única pista que nos dá Simone é de que se trata de um livro de poesia e que, ao que tudo indica, os poemas lidos são sempre os mesmos.

Borda com borda, corpo-leitor e corpo-texto remetem para o que vem a ser o processo de escritura: um "tocar na extremidade", como sugere Jean-Luc Nancy em Corpus, ensaio filosófico do início dos anos 1990. Ele parte da frase cristã dita durante a eucaristia - Hoc est enim corpus meum (Este é o meu corpo) - para refletir sobre a questão da presença e do valor do corpo no Ocidente. No momento da eucaristia, do sacrifício, pode-se comer o corpo de Deus (a hóstia consagrada), fundir o corpo humano ao corpo de Deus (que para uns está representado na hóstia e, para outros, está de fato lá). Como sabemos, essa imagem exerceu forte impacto sobre o imaginário que há 
pouco mais de 2 mil anos forjamos acerca do corpo: as almas dos homens são redimidas, salvas, pelo corpo invisível de Deus. As relações entre pensamento (em especial a filosofia, mas também a literatura) e corpo, principalmente a partir da Era Cristã, estariam marcadas, diz Nancy, pela necessidade de representar (de tapar) uma não-presença.

Nancy argumenta que na atualidade o corpo deve tomar a palavra a fim de poder pensar a si mesmo, ou seja, realizar sua própria escrita. Nada mais subversivo. Afinal, infelizmente, no imaginário comum nós salvamos nossos corpos quando fazemos deles “corpos da saúde, dos esportes e do prazer" (Nancy, 2008, p.7), produzindo, de forma ao mesmo tempo ostensiva e sutil, um controle por meio da representação de "carne, pele, rostos, músculos" (Idem, Ibidem): apenas os corpos em que esses elementos são dignos de valor estão aptos a figurar em nosso regime de visibilidade, a "circular", para usar o termo de Nancy. Restaria, mesmo assim, uma multidão de corpos que escapam e que "se multiplicam". Ela é formada por corpos "famintos, espancados, assassinados, inquietos, às vezes até rindo ou dançando" (Idem, Ibidem, p. 9).

Os corpos que ainda não foram salvos por Deus, pela ciência ou pelo capital não estão inscritos no atual regime de visibilidade, mas excritos. Eles permitem a Nancy forjar uma imagem extrema: a de corpos que "estão muito distantes e que vêm em nossa direção"; eles estão em nosso horizonte, eles são a multidão. (Idem, Ibidem) Com base nas noções de fora, de extra e de espacialidade (e, consequentemente, de limite), Nancy pensa os corpos em ação como agentes capazes de realizar uma escrita no mundo (uma escrita poético-política?). Ela seria a das superfícies e operaria pelo toque, manifestando-se sempre no exterior. Nesse sentido, sua reflexão toma vulto quando começa a pensar a escrita do corpo a partir de algo prosaico: o ato de escrever. No ensaio, escrever comparece como uma atividade corporal que não pode ser dissociada dos movimentos de excrita, de excreção por ser, em sua essência, produtora de um evento que acontece fora: da extremidade do escritor, de sua mão, sai o texto que alcançará o leitor em sua pele.

A literatura passa a ser um movimento para o exterior - a partida de um corpo em direção a outro. Aquilo que o leitor pode entender no texto é precisamente onde o corpo do escritor silencia. A "materialidade é subtraída à medida que o texto impresso significa: e isso ocorre aqui, na página lida e escrita". (Idem, Ibidem, p. 51) Ao escrever "aqui" o filósofo chama a atenção para o processo de escritura e leitura do próprio texto que está produzindo e para a dimensão corporal dessa dinâmica. "Corpos, para o bem ou para o mal, estão tocando uns aos outros nesta página, ou, mais precisamente, a página em si mesma é um tocar (de minha mão enquanto ela escreve, de suas mãos enquanto elas seguram este livro)" (Idem, Ibidem).

Parece-nos que essa relação de toque no aqui e agora está em questão na cena de leitura de Ulises. Além disso, o fato de a leitura debaixo do chuveiro ser uma ação repetida semanalmente provoca uma opacidade na relação entre o personagem e o livro. Ulises não consegue apreender seu objeto de leitura, dar conta de seu conteúdo, muito 
menos atravessá-lo, passar para outro título. Embora o papel se molhe, o livro resiste. Será isso o que leva o poeta a reencenar um gesto tão sem sentido? Haveria um limite impossível de transpor que ele não pode abandonar? "A escritura toca os corpos ao longo do limite absoluto separando o sentido de um da pele e dos nervos do outro. Nada passa através, e é por isso que há o tocar" (Nancy, 2008, p. 11). No objeto livro há algo de espesso (e atraente) que leva o personagem Ulises a reencenar semanalmente um corpo a corpo. No entanto, não consegue explicar a Simone Darrieux por que o faz. Tudo indica, ao menos é o que o relato de Simone nos faz crer, que levar o livro de poesia para o banho era muito mais uma compulsão do que uma experiência de decodificação ou uma atitude que levava a algum fim. Em outras palavras, trata-se de um contato não-racional em que as funções cognitivas ficam reduzidas à sua potência mínima. Como afirma Nancy, podemos "ver a leitura como algo que não é deciframento: tocar e ser tocado, estar envolvido com as massas dos corpos" (Idem, Ibidem, p. 87) - é disso que trata não só a cena de Ulises no banho como a descrição feita por Sofía sobre o efeito que o corpo do poeta produz nos livros (estes apodrecem, florescem, ganham cores alucinantes!).

Mas até que ponto é possível sustentar a proposição de Nancy no que tange ao ato de leitura e escritura? Embora entenda a potência de escrita de um corpo como algo capaz de dividir outros corpos sem significá-los, ele mesmo reconhece que o processo de atribuição de significado será algo inevitável: "somos organizados para que isso aconteça" (Idem, Ibidem, p. 83). Ainda assim, mesmo diante do inevitável, o pensamento que ele deseja produzir não teria nada, diz, de semiologia, mitologia ou fenomenologia - seria algo gerado e escrito para os corpos, devotado a eles. Tratar-se-ia de um desejo de descartar tanto a imanência quanto a transcendência? Se assim for, o que sobraria? Propõe-se uma noção radical: a leitura seria uma recepção superficial feita por um corpo, e o sentido do texto lido algo produzido pelas faculdades intelectuais deste corpo quando sua corporalidade começa a se calar. "Em nenhum momento seria uma questão de 'sensação', 'percepção', 'sinestesia' - derivações, todas elas, das 'teorias do conhecimento', todas laboriosos avatares da 'representação' e da 'significação' " (Idem, Ibidem, p. 99).

Embora desafiador porque aponta para o desconhecido, o ato de pensar leitura e corporalidade afastando-se das sensações e da sinestesia traz em si mesmo um limite sempre desafiado. Primeiro, porque ler e escrever é começar a dizer, e dizer é produzir um sentido. Segundo, porque mesmo quando o corpo explicita algo em sua fala muda, isso se dá pelos sentidos, seja a audição, a visão, o tato ou o olfato. É o que podemos verificar em um dos depoimentos de Amadeo Salvatierra, um senhor de idade que em janeiro de 1976 conta a alguém sobre a noite que passou com jovens poetas desejosos de conhecer o paradeiro da vanguardista Cesárea Tinajero:

Continuei remexendo nos papéis, e o outro rapaz se levantou da cadeira e foi examinar minha biblioteca. Eu, na verdade não o via, só o ouvia, dava um passo, pegava um livro, colocava no lugar, eu ouvia o barulho do dedo dele percorrendo a lombada dos meus 
livros! Mas não o via. Eu tinha me sentado de novo, posto as notas de volta na carteira e examinava com mãos trêmulas, numa certa idade não se pode beber com tanta alegria, meus velhos papéis amarelados. Estava com a cabeça abaixada, os olhos meio turvos, e o rapaz chileno se movimentava por minha biblioteca em silêncio, eu só ouvia o ruído de seu indicador ou do mindinho, ah, que rapaz mais danado, percorrendo a lombada dos meus calhamaços como um bólido, o dedo, um zumbido de carne e couro, de carne e papelão, um som agradável ao ouvido e propício ao sono, que foi o que deve ter acontecido, porque de repente fechei os olhos (ou talvez eles já estivessem fechados) [...] (Bolaño, 2010, p. 247).

Amadeo ouve um zumbido de carne, couro e papelão. Esse ruído o impressiona e o embala até o sono. Não pode dizer, porque dormiu, se o tal rapaz chegou a ler algum dos livros. Aqui importa mais a iminência da leitura, o primeiro contato do leitor com o livro, do que a experiência cognitiva que ocorre a partir do momento em que se passa a decodificar letras e fonemas. O que Amadeo ouve não são palavras - não é a leitura do "rapaz chileno" (seria Arturo Belano?) -, mas uma linguagem paralela à das palavras. Talvez por isso mesmo a cena não se desdobre: o sentido dos livros não aparece, o ato de percorrê-los com a carne da mão não produz continuidades.

Enquanto o texto de Bolaño silencia a leitura, mas não o toque, Corpus empurra a reflexão para um lugar impensado - quer apontar para o sentido como algo que não precisa ter início (para um livro que não precisaria ser aberto?): "Não se trata da 'origem do sentido' nem do 'sentido de origem'. Porque sentido não tem origem, porque ser-sem-origem e vir-para ser-extendido, ser-criado, ou pesar-isso, de fato, é 'sentido'”' (Nancy, 2008, p. 95). Antes do limite que a leitura impõe, o sentido dos corpos já estaria em curso, mas tampouco seria um mistério. Para Nancy, os corpos não precisam significar, embora seja exatamente isso que, segundo ele, não pare de acontecer: "O corpo significante - todo o corpus de corpos filosóficos, teológicos, psicanalíticos e semiológicos - encarna apenas uma coisa: a contradição absoluta de não ser capaz de ser um corpo sem ser o corpo de um espírito" (Ibidem, p. 69). A literatura, ou ao menos as interpretações feitas a partir dela, tornaria isso ainda mais evidente. Lida como "uma encarnação da filosofia" (Idem), como algo capaz de tocar, mas de maneira protegida, distanciada e "espiritual", essa forma de arte seria um reservatório de corpos saturados de significação, todos engendrados para significar.

"Se há alguma coisa para além disso", ou seja, uma literatura que não seja significante nem significado, esse material "vai fornecer algo que não seja nem signo nem sentido, e assim sendo não será sequer escrito. Será uma escritura, se 'escritura' indicar exatamente aquilo que desvia da significação, sendo, portanto, excrita" (Ibidem, p. 71). Em Os detetives selvagens talvez não haja corpo mais desafiador à proposição de Nancy do que o de Cesárea Tinajero: se em alguns momentos ele significa, em outros parece ir ao encontro de uma excritura. "Cesárea não tinha nada de poética. Parecia uma pedra ou um elefante. Suas nádegas eram enormes e se mexiam ao ritmo que seus braços, dois troncos de carvalho, imprimiam ao esfregar e enxaguar a roupa" (Idem, Ibidem, p. 615). Cesárea Tinajero: massa de carne, ossos e pele que se autoexilou em 
um vilarejo no deserto, corpo que saíra, por opção própria, do círculo literário ao qual pertencera. Certamente ela não era o que se esperava encontrar, ou, melhor dizendo, não era o que se supunha ser um corpo poético: não significa poesia, não se identifica com a imagem do poeta, mas significa alguma coisa que não é poesia e que, no entanto, não se consegue nomear.

Nádegas enormes, braços como troncos de carvalho. A descrição debochada que confere ao corpo de Cesárea uma dimensão mastodôntica, e até cômica, é feita por García Madero e está em seu diário, no dia 31 de janeiro de 1976, um mês depois que ele, Belano e Ulises partiram da capital mexicana com a prostituta Lupe a bordo do Impala de Quin Font, em direção ao norte do México. Não estavam somente atrás da poeta real-visceralista - o nome que dão ao próprio movimento, nos anos 1970, é uma homenagem declarada ao movimento de vanguarda liderado por Cesárea nos anos 1920 - cujos poemas não tinham lido. Também fugiam do cafetão de Lupe, Alberto, e do policial corrupto que o acompanhava.

Corpos que fogem e ao mesmo tempo buscam outro corpo, o de uma poeta que nos anos 1970 sobrevivia como lavadeira no povoado de Villaviciosa, em pleno deserto mexicano. "Seus cabelos chegavam praticamente até a cintura. Ela estava descalça. Quando a chamamos, ela se virou e nos encarou com naturalidade" (Idem, Ibidem, p. 615). Cesárea leva os jovens para sua casa, onde acumula dezenas de cadernos pretos em que escreve faz anos. Conversa somente com Belano e Ulises - García Madero e Lupe adormecem, estão exaustos -, mas não se sabe o quê, já que o autor do diário descansa em outro cômodo. Seria sobre o que escrevera ao longo de tanto tempo? Ou sobre o que lera? Disso só se vislumbram volumes de texto empilhados: dois dias antes, em 29 de janeiro, ao pararem na cidade de Santa Teresa (a mesma que em 2666 abrigará os crimes contra mulheres), García Madero, Belano, Ulises e Lupe conversam com uma professora que conhecera Cesárea em 1936. Ambas trabalharam na mesma escola e ficaram amigas durante os anos em que a poeta morou na cidade. Embora observasse que Cesárea lia e escrevia muito, a professora já "não se lembrava de nenhum dos livros que [Cesárea] tirava da biblioteca e que costumava carregar por toda parte". Tampouco sabia, até o momento em que conversou com os rapazes, que sua amiga era uma poeta, mesmo recordando que "em muitas ocasiões a vira escrever, sentada na sala vazia, num caderno de capa preta muito grosso que [...] sempre trazia consigo" (Idem, Ibidem, p. 608).

Ulises, García Madero e Belano não têm diante de si um enigma, mas uma surpresa quando a poeta aparece, com seu corpo imenso e grotesco: à sua frente está apenas um corpo imenso e um tanto risível. Graças a seu tamanho são, inclusive, protegidos da morte, como se verá uma ou duas páginas adiante. É o leitor de $O s$ detetives selvagens que se depara com a pergunta: o que teriam Ulises e Belano dito à Cesárea para que, pouco tempo depois, ela entrasse com eles no Impala e se colocasse entre García Madero e Lupe no banco de trás do carro? Teriam falado sobre sua poesia, perguntado sobre o que lia e escrevia? Teriam dito que também eram poetas? O que fez 
com que Cesárea pegasse a estrada com eles, saísse do povoado no entardecer? Para onde iam?

Impossível saber, assim como é ilegível a atitude de Cesárea quando um carro vem na direção contrária ao deles em plena estrada. Interpondo-se à frente do Impala e levantando consigo uma nuvem de poeira, o veículo, um Camaro, obriga-os a frear. Dele saem Alberto, o cafetão, e seu amigo policial. Cesárea desce do Impala, juntamente com Belano e Ulises. Do banco de trás, García Madero e Lupe acompanham o desenrolar da cena - que, embora tensa, traz em si um humor jocoso graças à aparência do corpo de Cesárea. "Pela janela vi Belano avançar fumando, com a outra mão no bolso. Junto dele vi Ulises Lima, e um pouco mais atrás, balançando como um navio de guerra fantasma, vi o dorso encouraçado de Cesárea Tinajero" (Idem, Ibidem, p. 617).

Alberto exige que Belano lhe entregue Lupe, e o poeta não oferece resistência. No entanto, mal dá dois passos, o cafetão é atacado por Belano, que lhe esfaqueia o peito, matando-o. Em seguida, Ulises ataca o policial e tem início uma luta corporal em que a massa espessa de Cesárea impede García Madero de entender com precisão o que acontece:

Depois vi Ulises Lima se jogar sobre ele. Ouvi um disparo e me agachei. Quanto tornei a levantar a cabeça do banco traseiro, vi o polícia e Lima rolando no chão até pararem na beira da estrada, o polícia em cima de Ulises, a pistola na mão do polícia apontando para a cabeça de Ulises, e vi Cesárea, vi a massa enorme de Cesárea Tinajero, que mal podia correr mas que corria, abatendo-se sobre eles, ouvi mais dois tiros e saí do carro. Custou-me apartar o corpo de Cesárea dos corpos do polícia e do meu amigo. Os três estavam manchados de sangue, mas só Cesárea estava morta. Tinha um buraco de bala no peito (Ibidem, pp. 617- 618).

Corpos em ação sob o sol, poeira e sangue. A sucessão de movimentos que García Madero descreve em seu diário é definida por ele como algo "confuso". O enorme corpo de Cesárea - o mesmo que naquele dia lavava roupa agachado - interpõese entre os de Ulises e do policial, e tão espesso quanto seu dorso encouraçado é o motivo que a faz agir heroicamente: em vez de criar um corpo grande cuja superfície extensa se oferece generosamente à leitura, Bolaño escreve a densidade da carne, ampliando-a até que deixe de fazer sentido, rumando para a extinção. Ainda assim, trata-se de uma cena romântica, mas não ingênua, já que possui certo grau de comicidade: uma poeta morre lutando, não sem antes correr de forma desajeitada em direção a seu destino. Isso dá contornos não à literatura de Cesárea, aos cadernos pretos nos quais escreveu, mas ajuda Bolaño a, antes de mais nada, desenhar a figura de poeta que lhe é cara - alguém que comete atitudes extremas, insensatas, e que graças a isso tem a chance de definir o futuro (a liberdade de Lupe, por exemplo); alguém capaz de estender a escrita poética e levá-la para a vida, para "o aqui e agora". Cesárea se alinha em ímpeto e coragem, atributos sem dúvida românticos, à geração de poetas que luta a seu lado. Essa geração é representada por Belano e Ulises e está perdida a priori, mas 
ainda assim insiste em ser vanguarda, em combater à frente. Quanto ao senso de humor fino, parece-nos que ele seria uma maneira de tornar a cena romântica sem romantizá-la, ou mesmo de apontar um certo ridículo que existe em todo ato heróico.

Para o leitor de Os detetives selvagens, junto com Cesárea morre a possibilidade de decifrá-la - ela é encontrada, mas não explicada. O desejo de torná-la inteligível surge à medida que, acompanhando a segunda parte do diário de García Madero, seguem-se os rastros da poeta durante um mês (de $1^{\circ}$ a 31 de janeiro de 1976). Antes que sua poesia e sua vida sejam esclarecidas, ela morre, e esse fato é provocado de forma não-intencional pelos leitores Belano e Ulises. Eles não só enterram o corpo de Cesárea no deserto como nascem, depois disso, de forma diferente na estrutura narrativa: à exceção dos depoimentos de Amadeo Salvatierra e do primeiro relato de Laura Jáuregui e Perla Avilés, as dezenas de pessoas que falam sobre os dois poetas em Os detetives selvagens estão em tempos e lugares posteriores a janeiro de 1976 e à cena da morte de Cesárea no deserto de Sonora. A dimensão mítica que Ulises e Belano adquirem (tal como Cesárea, em sua ausência, se apresentava para eles) é verificável à medida que os dados históricos que se podem colher sobre os dois em todos os depoimentos não dão conta de esclarecê-los, ou melhor, de inscrevê-los com precisão historicista.

\section{2)Ver para ler}

O recuo da autora Cesárea e o avanço dos leitores Belano e Ulisses têm na morte dela a alegoria máxima, mas não a primeira. Na parte inicial do diário, García Madero deixa claro que os jovens poetas criam o real-visceralismo para homenagear Cesárea, fundadora de um movimento homônimo na década de 1920, porém mencionada em entrevistas e textos por integrantes do estridentismo ${ }^{i}$. Ela é madrinha não consultada, autora de poemas que ninguém sabe quais são. É como se Belano e Ulises desejassem alinhar-se com quem ou o que ainda não conhecem, mas cuja atitude rebelde - a de fundar o próprio movimento - lhes inspira. "Não lemos nada dela, disseram, em lugar nenhum, foi isso que nos atraiu" (Bolaño, 2010, p. 166). Já em um dos depoimentos de Amadeo Salvatierra, mais precisamente em que lemos, junto com os personagens, a única poesia de Cesárea que puderam encontrar, Belano e Ulises ${ }^{\mathrm{ii}}$ se destacam como intérpretes às avessas:

Sion 


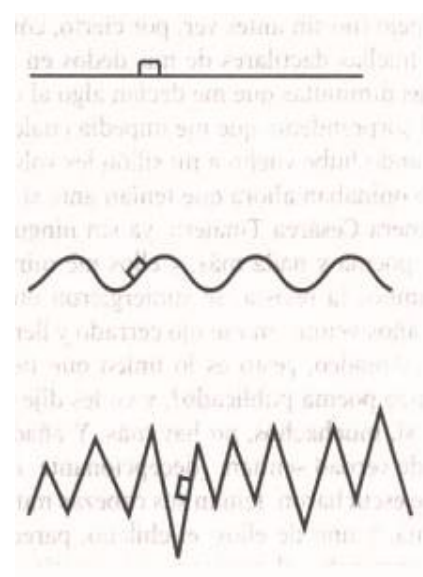

Aqui se impõe a tarefa de leitores vagabundos: admitir que não é preciso haver um enigma na poesia, que ela não deve ser decifrada - e que não precisa ser levada a sério. Ao menos é o que Belano e Ulises dizem a Amadeo, que há quase cinquenta anos diz tentar entender o poema visual que Cesárea publicou na única edição de Caborca, revista que ela mesma fundou na década de 1920. Quando o velho lhes pergunta se conseguiram solucionar o mistério que é a imagem do poema, Belano e Ulises lhe encaram e dizem: "não há mistério, Amadeo" (Idem, Ibidem, pp. 388-389).

Tarefa: ver a poesia como um corpo. Melhor dizendo, trata-se de ver a poesia, mas também de rir dela, não apenas de lê-la. Herdeiro, como toda poesia de vanguarda de sua época, da proposta de Mallarmé em Un Coup de dés, o poema de Cesárea radicaliza o desafio à recepção quando cria para si um espaço próprio - o fundo branco da página e o silêncio; só que aqui, esses elementos aparecem como uma sátira à ambição das vanguardas. Ao apresentar uma escritura sem palavras, retirando do leitor a possibilidade de encontrar um sentido dado, "Sion", poema de vanguarda porque é antipoema, mostra a recusa em construir um sentido, mas também o quanto pode ser risível essa pretensão.

Segundo Peter Bürger em A teoria da vanguarda, os procedimentos com intenção antiartística apontam de forma direta para o êxito das vanguardas junto à recepção das gerações seguintes: transformar a categoria da obra de arte e romper com o limite da representação. Na poesia, segue-se o caminho aberto por Mallarmé no final do século XIX: faz-se uma aposta no jogo da recepção participativa, mas não subjetivizada, liberada de tentar encontrar no poema, no texto, uma identificação.

Comentando as instruções de Tristan Tzara em "Como fazer um poema dadaísta" e de André Breton no "Manifesto surrealista", Bürger chama atenção que nesses textos estão a polêmica levantada contra a criação individual dos artistas e a intenção de estimular uma atividade nos receptores. "Os textos automáticos, é preciso lê-los, também neste sentido, como instrução para uma produção particular. Mas essa produção não pode entender a si mesma como artística, e sim interpretar-se como parte de uma práxis vital emancipadora" (Bürguer, 1997, p. 112). A vanguarda quer que a 
recepção seja atingida na vida, fora do espaço protegido e institucionalizado da representação e dos museus legitimados pela sociedade burguesa.

Parece que falta a Amadeo, embora fosse ele também um vanguardista na década de 1920, a capacidade de aceitar a provocação do poema de Cesárea: "não me decifre, devore-me", e é precisamente isso o que conseguem fazer Belano e Ulises. Leitores de poetas como o chileno Nicanor Parra ${ }^{\text {iii }}$, o antipoeta, pertencem à geração neovanguardista, herdeira das primeiras, e são capazes de aplicar, com fins artísticos, "os procedimentos que a vanguarda idealizou com intenção antiartística" (Idem, Ibidem, p.113). Devoram e recriam: "Não há mistério, Amadeo [...] Comecemos pelo título, um deles disse, o que acha que significa? Sion, o monte Sion, em Jerusalém, falei sem hesitar [...] Agora vamos ver a primeira seção do poema, o que temos aí? Uma linha reta e sobre ela um retângulo, falei” (Bolaño, 2010, p. 412).

A partir da resposta de Amadeo, engraçada porque óbvia, Belano e Ulises vão desmembrar o poema, isolando as linhas reta, ondulada e quebrada do retângulo desenhado sobre cada uma delas:

Olhe só para a linha reta. O que você vê?

Uma linha reta, falei. Que outra coisa eu poderia ver, rapazes? E o que uma linha reta lhe sugere, Amadeo? O horizonte, falei. O horizonte de uma mesa, falei. Tranquilidade?, um deles perguntou. Sim, tranquilidade, calma. Bem: horizonte e calma. Agora vejamos a segunda seção do poema:

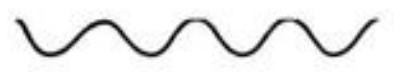

O que está vendo, Amadeo? Uma linha ondulada, ora essa, que mais poderia ver? Bem, Amadeo, disseram, agora você vê uma linha ondulada, antes você via uma linha reta que sugeria calma, e agora você vê uma linha ondulada. Continua sugerindo calma? Não, respondi, compreendendo de repente aonde queriam chegar, aonde queriam me levar. O que sugere a linha ondulada? Um horizonte de colinas? O mar, ondas? Pode ser, pode ser. Uma premonição de que a calma se altera? Movimento, ruptura? Um horizonte de colinas, falei. Talvez ondas. Agora vejamos a terceira seção do poema:

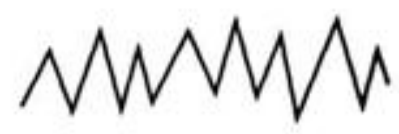

Temos uma linha quebrada, Amadeo, que pode ser muitas coisas. Os dentes de um tubarão, rapazes? Um horizonte de montanhas? A Sierra Madre ocidental? Bem, muitas coisas.

[...]

Entendeu?, eles perguntaram. Bem, para dizer a verdade, não, rapazes, falei. O poema é uma brincadeira, eles disseram, é muito fácil de entender. Amadeo, olhe: acrescente a cada retângulo de cada seção uma vela, assim: 


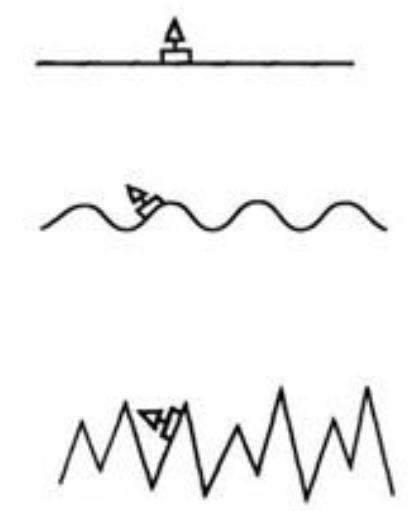

\begin{abstract}
O que temos agora? Um barco?, falei. Exatamente, Amadeo, um barco. E o título, Sion, na realidade oculta a palavra Navegación. Só isso, Amadeo, muito simples, não há mais mistério, os rapazes disseram, e eu gostaria de ter lhes dito que me tiravam um peso da alma [...] (Idem, Ibidem, pp. 412-414).
\end{abstract}

"Sion" não é um poema sujeito a conexões lógicas - retirar o retângulo das linhas e depois devolvê-lo, acrescentando-lhe uma vela e transformando-o em um barco é um procedimento arbitrário que despreza relações de sentido prévias, ou seja, é uma interpretação que se fixa no poema, no espaço que ele ocupa, prescindindo de um referencial fora da página e lidando apenas com o que o "texto" oferece em sua constituição artificial, inorgânica iv . "Em lugar de pretender captar um sentido mediante as relações entre o todo e as partes da obra, [o receptor] tratará de achar os princípios constitutivos da obra, a fim de encontrar neles a chave do caráter enigmático da criação", diz Bürger (1997, p. 147). É isso o que fazem Belano e Ulises. Aqui, no entanto, o dispositivo de leitura antirrepresentativo é ridicularizado na própria interpretação que se realiza de "Sion". Nesse sentido, o enigma é o de não haver enigma, mas um tipo de humor que na interpretação de Belano e Ulises produz um duplo sentido cômico: a renúncia em procurar um significado prévio na obra de arte resulta numa leitura bem-sucedida do ponto de vista de Bürger, assim como numa produção de sentido que debocha da ambição de não produzir sentido.

Podemos inclusive afirmar que a comicidade é um efeito de leitura que aparece tanto na desconstrução da imagem idealizada da poeta Cesárea quanto na dessacralização do único poema dela que Belano e Ulises puderam encontrar. Como afirma Verena Alberti em $O$ riso e o risível na história do pensamento, "o riso situa-se para além do conhecimento, para além do saber, e, por isso mesmo, coincide com a filosofia do não-saber" (Alberti, 2002, p. 14). Alberti, que em seu livro se dedica a pensar as relações entre filosofia, literatura e riso no Ocidente em diferentes momentos, indo desde a antiguidade até o século XX, na passagem aqui citada refere-se a alguns textos de George Bataille, que, por sua vez, se afirma tributário de Nietzsche nesse tópico. Em livros como A gaia ciência, Nietzsche teria sido o primeiro a apostar no valor do cômico, diretamente ligado à desrazão, para a produção de um discurso em que 
a gargalhada pudesse fazer frente "à toda verdade séria", assim como à "crença na razão" e à "positividade da existência" (Idem, Ibidem, pp. 15). Ele teria sido o precursor de uma corrente, no pensamento moderno, a "conferir ao riso um lugar-chave no esforço filosófico de alcançar 'o impensável' " (Idem, Ibidem, p. 16). Isso vai ao encontro do que se passa na leitura de "Sion": ante aquilo que não sabem, Belano e Ulises recorrem a uma razão insana, que de tão absurda soa hilária para o leitor de $O s$ detetives selvagens.

\footnotetext{
' O estridentismo foi um movimento de vanguarda real que reuniu no México dos anos 1920 poetas, artistas plásticos, músicos e intelectuais. Em Os detetives selvagens, alguns integrantes do estridentismo, como Arqueles Vela, Germán List Arzubide e Manuel Maples Arce são ficcionalizados. Arce, inclusive, figura como uma das dezenas de pessoas que dão seu depoimento sobre Belano e Ulises. Estes o teriam visitado pedindo informações sobre as vanguardas de sua época. Nos depoimentos de Amadeo Salvatierra, também estridentista, descobre-se que Cesárea, antes de ser real-visceralista, participou do movimento liderado por Arce. Sob impacto dos efeitos da revolução mexicana e dos movimentos de vanguarda europeus, principalmente o cubismo, o futurismo e o dadaísmo, o estridentismo procurou combinar as expressões da cultura popular mexicana com as inovações formais propostas pelas vanguardas europeias. A tentativa de anular a separação entre arte e vida aqui se verifica na experiência que ocorre em 1925 na cidade de Xalapa, que seria rebatizada pelos integrantes do movimento de Estridentópolis. Ali se realiza um trabalho artístico, cultural e educativo em colaboração com a Universidad Veracruzana e apoiado pelo governador de Veracruz, Heriberto Jara, até este ser deposto, em 1927, pelo governo federal, por defender o direito dos trabalhadores locais frente a petroleiras inglesas e norte-americanas. De volta à ficção: depois de romper com o movimento estridentista e criar o realvisceralismo, que divulga editando a primeira e única edição da revista Caborca, Cesárea decide ir embora do Distrito Federal mexicano.

ii Afirmamos a presença de Ulises e Belano nos depoimentos do personagem Amadeo Salvatierra correndo algum risco, já que, na estrutura temporal do romance, os poetas e Amadeo não poderiam estar no mesmo lugar: todos os relatos de Amadeo ocorrem na Cidade do México, em janeiro de 1976, mês em que a dupla de poetas deixa a cidade em direção ao deserto de Sonora. Dessa forma, concluímos que ou o depoimento de Amadeo, embora de janeiro de 1976, se refere a um encontro entre ele, Belano e Ulises em algum mês do ano de 1975, ou que a confusão tenha sido gerada propositalmente por Bolaño a fim de colocar em xeque o lugar investigativo do leitor.

iii O chileno Nicanor Parra (1914-) é a grande referência em poesia espanhola do século XX para Roberto Bolaño, e isso fica claro em diferentes momentos de Os detetives selvagens, assim como em muitas de suas entrevistas, ensaios e discursos. Conhecido como antipoeta, Parra tem uma história ligada à arte popular, é professor de física e matemática e também artista visual. Começou a publicar em 1937, mas foi em 1954, quase vinte anos depois, que lançou o livro que o consagrou, Poemas y antipoenas. Ali nascia algo novo: com uma linguagem trivial e direta, Parra fez uso incisivo do senso de humor para tratar de temas do homem contemporâneo. Poemas y antipoemas está ligado a uma iniciativa a que dera início dois anos antes: ao lado de Enrique Lihn e Alejandro Jodorowsky, Parra publicou, a partir de 1952, edições do Quebrantahuesos, poesia-mural elaborada com recortes de jornal em que cânones literários, políticos e culturais eram postos à prova sem dó. Para saber mais, ver, nas referências, BAY (s/d) e LETELIER (2011).

${ }^{\text {iv }}$ Bürger estabelece, a partir da teoria estética de Theodor Adorno, uma distinção entre obras de arte orgânicas e inorgânicas. Enquanto as primeiras seriam aquelas simbólicas, em que a unidade do geral e do particular se dá sem mediações, as segundas, inorgânicas, seriam alegorias em que o momento da unidade funcionaria de outra forma, menos específica, e certamente dependente de uma mediação (via receptor). Trata-se, se pensarmos a partir do conceito de alegoria benjaminiano, como sugere Bürger, não de negar qualquer unidade, mas um tipo específico de unidade, em que há plena e natural conexão entre as partes e o todo. "Uma comparação das obras de arte orgânicas com as inorgânicas (vanguardistas), desde o ponto de vista da estética da produção, encontra uma ferramenta essencial no que chamamos montagem, com o que coincidem os primeiros elementos do conceito de alegoria de Benjamin. $\mathrm{O}$ artista que produz uma obra orgânica [...] maneja seu material como algo vivo, respeitando seu significado aparecido em cada situação concreta da vida. Para o vanguardista, ao contrário, o material é só material; sua atividade consiste principalmente em acabar com a 'vida' dos materiais, arrancando-os do contexto onde realizam sua função e recebem seu significado" (1997, pp. 132-133).
} 
Referências bibliográficas

ALBERTI, Verena. O riso e o risível na história do pensamento. Rio de Janeiro: Jorge Zahar, 2002.

BAY, Carmen A. "Nicanor Parra, el francotirador de la poesia". Disponível em <http://cvc.cervantes.es/literatura/escritores/parra/biografia.htm.> Acessado em 21 fev 2013.

BOLAÑO, Roberto. Os detetives selvagens. São Paulo: Cia das Letras, 2010.

BÜRGER, Peter. Teoria de la vanguardia. Barcelona: Península/Biblos, 1997.

LETELLIER, Alberto M. Gabinete de lectura - Poesia visual chilena. Santiago de Chile: Metales Pesados, 2011

NANCY, Jean-Luc. Corpus. New York: Fordham University Press, 2008. 